\author{
Irena KHMILYAR, \\ orcid.org/0000-0003-3325-4165 \\ Postgraduate Student at the Department of Pedagogy and Innovative Education \\ Lviv Polytechnic National University \\ (Lviv, Ukraine) Irena.R.Khmiliar@lpnu.ua
}

\title{
NURSING PROFESSION THROUGH THE PERSPECTIVE OF THE SWISS LABOR MARKET
}

In the article, the problem of the development of nursing profession through the perspective of the Swiss labor market has been studied. The scientific-pedagogical and economic literature, which highlights different aspects of the research problem, and also documents of the international nursing organizations have been analyzed. The profession of a nurse has been defined as a specialist providing professional care to individuals, families, groups and communities, the sick and their relatives, persons with special needs, healthy citizens that envisages tasks performance for health maintenance and improvement, organization of preventive measures, preparation and labor support, assistance in acute diseases, recovery and rehabilitation, long-term care and palliative care. The complex of research methods (analysis and synthesis, systematization and generalization) has been introduced. Special features of the nurse labor market have been pointed out in Switzerland; the importance of professional migration, namely from Italy, Germany and France, which induces the specific nature of health workforce in the healthcare system of the studied country, has been emphasized. Working conditions of nurses (workload, wages, full-time/part-time employment) and their social security (paid annual vocation, financial, material or non-financial incentives) have been characterized. Positive and negative factors, characterizing the nursing profession and being of great importance for nursing practice, namely: independence in the performance of professional duties, professional status and sick pay rules, as positive ones; occupational burnout and change of workplace or even profession, as negative ones, have been examined. Nursing workforce (nursing support worker, licensed practical nurse, registered nurse) and their responsibilities has been analyzed. The essence of legal regulation in the development of nurses 'vocational training, which is implemented in accordance with the national interests of Switzerland and synchronized with the trends of the international labor market, has been highlighted. The research conclusions and prospects for further research have been presented.

Key words: health workforce classification, nursing profession, labor market, nursing workforce, Switzerland.

Ірена ХМІЛЯР, orcid.org/0000-0003-3325-4165 аспірантка кафедри педагогіки та інноваційної освіти Національного університету «Львівська політехніка» (Львів, Україна) Irena.R. Khmiliar@lpnu.ua

\section{ПРОФЕСІЯ «МЕДИЧНА СЕСТРА» КРІЗЬ ПРИЗМУ РИНКУ ПРАЦІ ШВЕЙЦАРІЇ}

Стаття присвячена висвітленню результатів дослідження проблеми розвитку професії медичної сестри крізь призму ринку прачі Швейцарї. Виконано аналіз науково-педагогічної та економічної літератури, присвяченої висвітленню різноманітних аспектів проблеми дослідження, а також документів міжнародних організацій у сфері сестринської справи. Означено професію медичної сестри як фахівия, щзо забезпечує професійний догляд за окремими особами, сім'ями, групами й громадами, хворими та їхніми родичами, особами з особливими потребами, здоровими громадянами, щзо передбачає постійне виконання завдань задля підтримання здоров'я та його покращення, організації профілактичних заходів, підготовки й допомоги при пологах, під час гострих захворювань, відновлення й реабілітації, тривалого догляду та паліативної допомоги. Представлено комплекс використаних методів дослідження (аналіз і синтез, систематизація та узагальнення). Акцентовано увагу на особливостях ринку праці сестринського персоналу у Швейцарії; підкреслено важливість професійної міграції, зокрема з Італії, Німеччини, Франції, щуо зумовлює специфіку кадрового потенціалу в системи охорони здоров'я досліджуваної краӥни. Презентовано умови праці медичних сестер (навантаження, оплата праці, прачевлаштування з повним/ неповним робочим днем), їхн соціальне забезпечення (оплачувана відпустка, наявність винагород матеріального/ нематеріального характеру). Виконано аналіз позитивних і негативних чинників, щзо характеризують професію медичної сестри й мають вагоме значення для професійної діяльності, а саме: незалежність під час виконання посадових обов'язків, професійний статус, норми оплати лікарняних листків - як позитивні, емоційне виснаження, зміна місия праці або зміна професії-як негативні. Охарактеризовано сестринський персонал (прачівника з догляду за хворими, лічензована практикуюча медична сестра, зареєстрована медична сестра) та його функиії. Акцентується увага на нормативно-правовому регулюванні розвитку професійної підготовки 
фахівиів із сестринської справи у Швейцарії, яке реалізується відповідно до наиіональних інтересів країни, які синхронізують тендениї міжнародного ринку пращі. Представлено висновки й перспективи подальших досліджень.

Ключові слова: класифікачія медичного персоналу, професія медичної сестри, ринок праці, сестринський персонал, Швейцарія.

Problem statement. At the beginning of the XXI century the health labor market underwent significant changes caused by active migration processes, vertical and horizontal professional mobility, the improvement of requirements for health workers' competence and personal readiness to work in a changing professional environment. Moreover, the development of the labor market for mid-level health workers is directly related not only to economic or political factors; social and cultural factors are also essential. In such a situation, it is important to monitor the changes introduced, since vocational education of nurses must meet requirements of society, needs and interests of employers.

Nowadays, in Ukraine medical reform continues, which is characterized by both positive and negative aspects; thus, it is necessary to study foreign experience in order to identify those constructive ideas which could be implemented in domestic practice. The experience of Switzerland is noteworthy, which has a developed healthcare system that guarantees its citizens access to highly qualified medical services throughout lives.

Analysis of relevant research and publications. It is worth mentioning that problems of nurses' vocational education, working conditions, social security of health workers are the subject of scientific discussions of numerous national and international scholars. Synchronization of the European and national legislations of health workers' professional education and healthcare system (Kapinus, 2012); classification of healthcare providers in the context of the recommendations of the World Health Organization (Pietro de, et al. 2015); human resource development (Schwendimann, et al., 2014; Ruzhylo, \& Terenda, 2020; Poghosyan, et al., 2009; Kravchuk, Danchak, \& Prokopchuk 2020); professional competence (Lukina, \& Mishurenko, 2018) etc. have been analyzed.

The aim of the article. The investigation of the development of vocational education of nursing workforce in Switzerland required the study of nursing profession in the context of the labor market needs. Thus, the aim of the article is to present the results of the analysis of the research problem.

Research methods. Theoretical methods of the research: analysis and synthesis of the Swiss legislation and regulations, as well as the recommendations of international organizations in the sphere of medicine and health care with the aim to identify international trends and features of the labor market for mid-level health workers; scientific-pedagogical and economic literature, which focuses on the theoretical aspects of the research problem; systematization and generalization of the research data with the aim to make conclusions and identify prospects for further investigation have been used.

Results. Despite the fact that Switzerland is not a member of the European Union, it maintains relations with the European Union, as reflected in numerous bilateral cooperation agreements, signed on the economic, social, cultural and political spheres. Kapinus (2012) notes that "Switzerland's experience of the European integration policy implementation is unique, as it is an example of the combination of consistent Euroscepticism and simultaneous advocacy of national interests within the framework of bilateral relations with the European Union" (p. 62).

As the results of the analysis of statistical data (NAREG, 2015) show, the Swiss labor market needs mid-level health workers to perform professional functions in hospitals, to provide long-term medical care depending on person's needs and to deliver medical care at home. In Switzerland the National Health Register (NAREG, 2015) was established with the aim to standardize data about the health workforce which have been updating since 2000 . The register provides data about persons with higher education in medicine and health care: doctors, dentists, pharmacists, nurses, physiotherapists, obstetricians, ergotherapists, etc. (NAREG, 2014). The National Health Register also contains information about the type of profession, graduation year, professional license, and employment data. According to statistics, Switzerland had 18 practicing nurses and 4.2 doctors per 1.000 population in 2015 (OECD, 2017).

It is considered that significant share of the nursing workforce constitutes professionals received higher vocational education abroad (foreign-trained nurses). This statistics shows that nurses trained in Germany, Italy, France, etc. from 2003 to 2017 in Switzerland (see Fig. 1). Aaccording to Figure 1, vast majority of the nursing workforce is made up of graduates getting diploma in German, Italian and French higher educational institutions. 


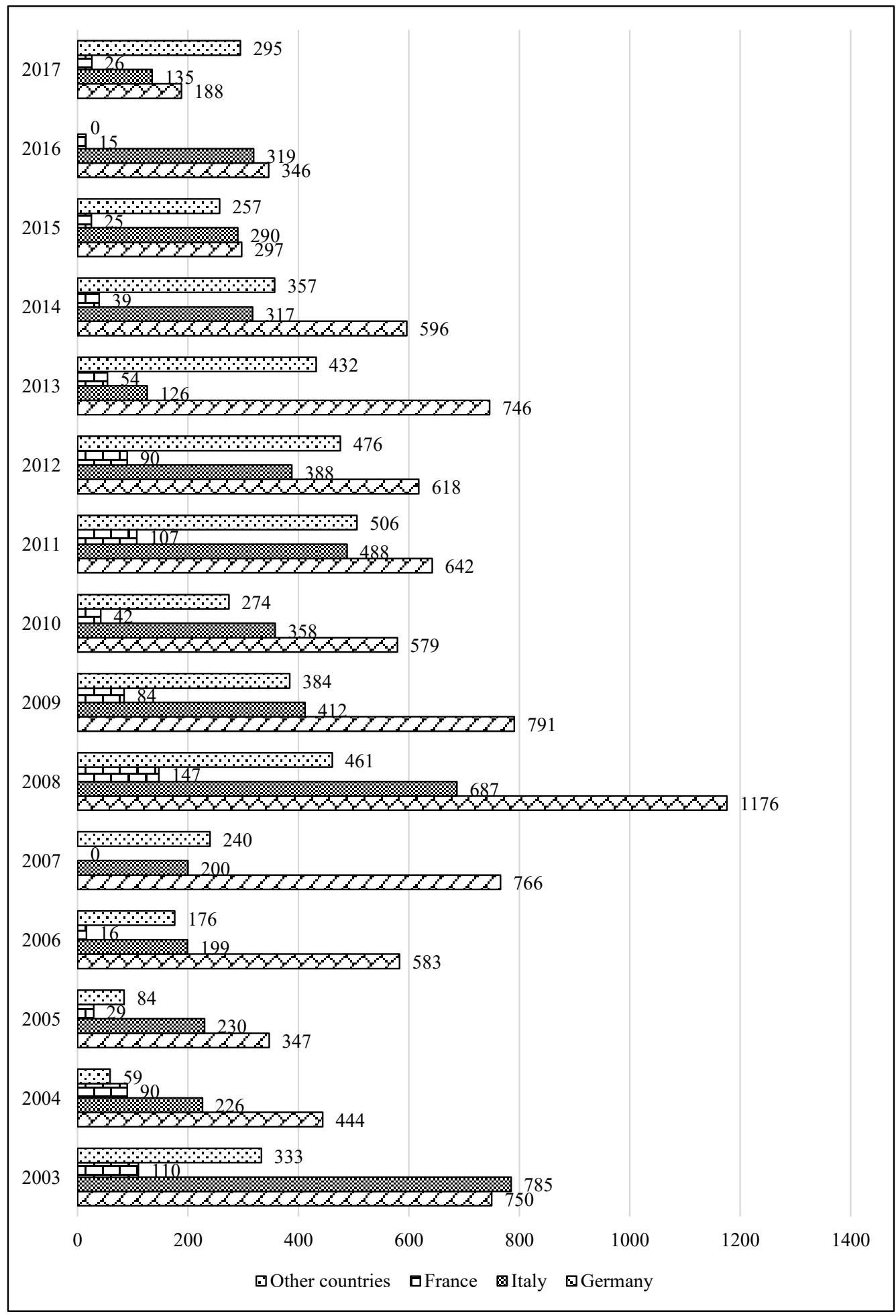

Figure 1. Ratio of nursing workers trained outside Switzerland

(Central Migration Information System, State Secretariat for Migration, 2018)

The Swiss healthcare system (including long-term care) is one of the largest labor markets and continues to grow rapidly, especially in 2020 , due to, inter alia, the spread of the Covid-19 pandemic.

In 2014, the healthcare system of Switzerland accounted for $11.8 \%$ of the labor force. The employment of the health care system was significantly higher than the rest of the economy, increasing in $17 \%$ from 2009 to 2014 , compared to $6 \%$ of total economy during the same period (Bundesamt für Statistik, 2015).

In general, the Swiss healthcare system comprises three groups of health professionals (see Table 1): university health professionals, including general practitioners, dentists and pharmacists; specialists in 


\begin{tabular}{|l|l|}
\multicolumn{2}{|c|}{ Classification of health professionals } \\
in Switzerland
\end{tabular}

psychology, namely psychotherapists and clinical psychologists; non-university health professionals, including nurses and midwives (Pietro de, et al., 2015).

It is necessary to mark that there are $40-43.5$ working hours per week for health workers, but there are 20-30 calendar days of paid annual vacation at the legislative level, depending on the cantonal regulations and the age category of the employee. Fulltime or part-time employment is also available for nurses. Regarding nurse's wage, it may differ due to the conditions set in the collective bargaining agreement concluded with the employer according to the current legislation. The collective bargaining agreement defines mechanisms of extra financial, material or non-financial incentives in addition to the basic wage (Pietro de, et al., 2015).

According to the statistics, annual net income of a registered nurse is 55.000-70.000 Swiss francs at the beginning of the professional career. But registered nursing professionals receive $60.000-85.000$ Swiss francs with 10 years of professional experience, depending on the canton, age and qualifications (Bundesamt für Statistik, 2015).

The Swiss labor market needs highly qualified nurses capable to perform their professional functions effectively. In this context, nurses' vocational education and training should be considered in the context of the demands of society, the needs of the labor market and the legal framework, in compliance with which training should be performed. In fact, according to Babych (2011), "in modern interpretation, the model of a specialist is determined as the system of features characterizing conformity degree of professional activity with the level of the development of a particular profession and includes the following parameters: requirements to a specialist, defined by the nature of professional tasks; knowledge and skills required in professional activity; specific social and psychological qualities of a personality ensuring effectiveness of professional activity" (p. 238).

The results of the study give grounds to assert that the legal regulation of the development of nurses' vocational training is implemented in accordance with the national interests of the studied country being synchronized with trends of the international labor market.

The Swiss Nurses Association is actively involved in the development of the mid-level health worker profession. In particular, the document has been published on prospects for the development of the nursing profession, which sets out norms and standards quality of nursing education and professional nursing practice (SBK-ASI, 2011).

The professional care, provided by nurses in Switzerland, is aimed at individuals, families, groups and communities, the sick and their relatives, persons with special needs, healthy citizens and envisages continuous tasks performance for health maintenance and improvement, organization of preventive measures, preparation and labor support, assistance in acute diseases, recovery and rehabilitation, long-term care and palliative care.

Obviously, this interpretation of the professional care is based not only on nurse's professional skills, but also on soft skills, since its efficacy depends on forming constructive relationship with people, without which tender loving care cannot be delivered. Relations with patient's family, the community, in which he/she lives, provides opportunity for the productive use of available resources, their identification, planning and organization of further activities and their realization.

It is important for modern nurses to have emotional, intercultural and social intelligence, since their work is based on patient's physical, psychological, spiritual, sociocultural, age and gender peculiarities. Therefore, modern nursing workforce requires professional values and attitudes in addition to knowledge, skills and competencies.

The results of scientific research show that health workers' positive or negative attitude towards working conditions and wages is important in delivery high-quality nursing services. In Switzerland, scientists found important factors for nurses as inde- 
pendence in the performance of professional duties ( $94 \%$ of the respondents), professional status ( $85 \%$ of the respondents), sick pay rules (85\% of the respondents) (Schwendimann, et al., 2014). In fact, national researchers point out that "study of international experience in the development of the nursing profession shows that rational use of the nursing workforce contributes to significant improvement in quality, accessibility and cost-effectiveness of health care delivery to the population, effective use of resources in health care, disease prevention" (Ruzhylo, \& Terenda, 2020, p. 38).

Negative factors, characterizing nursing profession of studied country, should also be identified. For example, about $15 \%$ of the respondents suffered from occupational burnout and $28 \%$ of the respondents contemplated to change their workplace or profession (Poghosyan et al., 2009).

Investigating the problem of mid-level health workers' occupational burnout, Kravchuk, Danchak, $\&$ Prokopchuk (2020), point out that nurse's work is performed in "human-to-human relationship model" ("person-centered model") and cannot conduct without constant tension. In particular, the main symptoms of burnout are: "physical (fatigue, insomnia, deterioration of health, manifestations of vegetative dysfunction), emotional (pessimism, cynicism, indifference, depression, feeling of loneliness and guilt), behavioral (impulsive behavior, constant fatigue, indifference to food, justification or tobacco, alcohol craving), intellectual (loss of interest at work, formal performance of work, indifference to new ideas) and social symptoms (loss of interest in leisure, social contacts and social activity, feeling of isolation, feeling of lack of support from family and friends)" (p. 62). It is worthwhile to agree with scientists Lukina \& Mishurenko (2018) that in this case it is necessary to develop emotional stability and emotional intelligence, to create skills to control own emotions. The main components of emotional intelligence are: understanding one's own emotions, understanding other people's feelings, controlling one's own emotions (Lukina, \& Mishurenko, 2018).

The International Council of Nurses (ICN), headquartered in Geneva, Switzerland, is of particular importance in the development of the nursing profession. The International Council of Nurses is a federation of over 130 National Nurses Associations representing more than 20.000 mid-level health workers worldwide. The International Council of Nurses, founded in 1899, is the world's first and largest international organization for health workers.

It should be noted that several categories of midlevel health workers are differentiated according to the level of education registration and so on in the Swiss labor market. It is worth mentioning a nursing support worker, who performs the role of nurse's assistant, and his/her duties include direct care for the sick at home or healthcare settings, performed under the supervision of a nurse. The Swiss legislation does not provide for the registration of such workers and granting the licences for their activities, special education, a defined scope of practice, etc. In practice, diverse titles are applied to this category as nursing assistant, auxiliary, worker support, orderly, aide, home support workers, personal care worker, health care assistant, and community health worker etc. (Nursing Care Continuum Framework and Competencies, 2008; Rafferty, Busse, Zander-Jentsch, Semeus, \& Bruyneel, 2019).

A licensed practical nurse is a person authorised to practise within the limits of a defined scope of practice and under the supervision of a registered nurse (Nursing Care Continuum Framework and Competencies, 2008; Rafferty, Busse, Zander-Jentsch, Semeus \& Bruyneel, 2019).

A registered nurse is an independent, self-reliant mid-level health caregiver working autonomously or in collaboration with other specialists. A registered nurse has an appropriate education, has passed the qualification exam, is included in the National Health Register, performs own practice in compliance with occupational standards (Nursing Care Continuum Framework and Competencies, 2008; Rafferty, Busse, Zander-Jentsch, Semeus, \& Bruyneel, 2019).

Considering the fact that continuous professional development is a "must" for professional activity; the term "advanced practice nurse" is used in Switzerland. This status indicates that a nurse is registered and considers to be an expert in nursing, has acquired an proficient knowledge base, skills and competencies for management decisions making. (Nursing Care Continuum Framework and Competencies, 2008; Rafferty, Busse, Zander-Jentsch, Semeus, \& Bruyneel, 2019).

Conclusions and prospects for further research. Thus, on the basis of the research, it is concluded that the nursing profession is in demand on the Swiss labor market. It develops in the context of the international labor market trends, the national legal and regulatory framework that takes into account the interests of employers, the demands of society and the level of competencies of healthcare workforce delivering patient-centered professional care and dealing with patients' families, social services, community.

The prospects for further scientific research include the analysis of nurses' competency that determines creation of meaningful contents of educational and professional programmes. 


\section{СПИСОК ВИКОРИСТАНИХ ДЖЕРЕЛ}

1. Бабич М. Відповідальність у структурі професійної моделі молодшого медичного спеціаліста. Психологія особистості. 2011. Вип. 1. № 2. С. 237-244.

2. Капінус О. Швейцарська Конфедерація у контексті формування європесьуого економічного простору. Вісник Львівського університету. Серія «Міжнародні відносини». 2012. Вип. 31. С. 62-71.

3. Кравчук Г., Даньчак С., Прокопчук О. Професійне вигорання медичних сестер як компонент робочого процесу. Медсестринство. 2020. № 2. С. 61-65.

4. Лукіна Г. О., Мішуренко О. В. Емоційна компетентність медичної сестри як складова її професійної компетентності. Медсестринство. 2018. № 4. С. 44-46.

5. Ружило Н. С., Теренда Н. О. Вивчення потреби в неформальній освіті серед молодших спеціалістів 3 медичною освітою закладів охорони здоров’я Івано-Франківської області. Медсестринство. 2020. № 2. С. 39-40.

6. Bundesamt für Statistik. Erwerbstätigkeit und Arbeitszeit - Detaillierte DatenDetaillierte Ergebnisse der BESTA. 2015. URL: http://www.bfs.admin.ch/bfs/portal/de/index/themen/03/02/blank/data/02.html.

7. Central Migration Information System, State Secretariat for Migration. Analyses by Swiss Health Observatory. Neuchâtel, 2018. URL: https://www.ncbi.nlm.nih.gov/books/NBK545726/.

8. NAREG. Nationales Gesundheitsberuferegister, Factsheet. Bern : Schweizerische Konferenz der Gesundheitsdirektorinnen und Gesundheitsdirektoren, 2014. URL: https://www.astrm.ch/files/Dokumente/News/Factsheet NAREG 20141212_d.pdf.

9. NĀREG. Nationales Gesundheitsberuferegister. 2015. URL: http://www.gdk-cds.ch/index.php?id=1013.

10. Nursing Care Continuum Framework and Competencies. Geneva, Switzerland : International Council of Nurses, 2008. 43 p.

11. OECD. (2017). Health at a Glance 2017: OECD Indicators. Paris, France : OECD Publishing. URL: http://dx.doi.org/10.1787/health_glance-2017-en.

12. Switzerland: Health System Review / C. Pietro de, P. Camenzind, I. Sturny, L. Crivelli, S. Edwards-Garavoglia, A. Spranger, F. Wittenbecher, W. Quentin. Health Systems in Transition. 2015. № 17 (4). P. 1-288.

13. Poghosyan L., Aiken L. H., Sloane D. M. Factor structure of the Maslach burnout inventory: an analysis of data from large-scale cross-sectional surveys of nurses from eight countries. International Journal of Nursing Studies. 2009. № 46 (7). P. 894-902.

14. Strengthening health systems through nursing: Evidence from 14 European countries / A. M. Rafferty, R. Busse, B. Zander-Jentsch, W. Semeus, L. Bruyneel. Copenhagen, Denmark : WHO. European Observatory on Health Systems and Policies, 2019.

15. SBK-ASI. Professionelle Pflege Schweiz - Perspektive 2020. Bern: Schweizer Berufsverband der Pflegefachfrauen und Pflegefachmanner, 2011. URL: http://www.sbk.ch/fileadmin/sbk/shop_downloads/de/Perspektive2020-dt.pdf.

16. Neuchâtel: Schweizerisches Gesundheitsobservatorium. Das Pflegefachpersonal in Schweizer Spitälern im europäischen Vergleich / R. Schwendimann, et al. Obsan Bulletin. 2014. № 3.

\section{REFERENCES}

1. Babych M. Vidpovidalnist u strukturi profesiinoi modeli molodshoho medychnoho spetsialista [Responsibility in the structure of junior medical specialist's professional model]. Psychology of personality. 2011. Vol. 1, № 2. P. 237-244 [In Ukrainian].

2. Kapinus O. Shveitsarska Konfederatsiia u konteksti formuvannia yevropeiskoho ekonomichnoho prostoru [The Swiss Confederation in the context of the European Economic Area formation]. Bulletin of Lviv University. Series: International Relations. 2012. Vol. 31. P. 62-71 [In Ukrainian].

3. Kravchuk H., Danchak S., Prokopchuk O. Profesiine vyhorannia medychnykh sester yak komponent robochoho protsesu [Professional burnout of nurses as a component of the working process]. Nursing. 2020. Vol. 2. P. 61-65 [In Ukrainian].

4. Lukina H. O., Mishurenko O. V. Emotsiina kompetentnist medychnoi sestry yak skladova yii profesiinoi kompetentnosti [Nurse's emotional competence as a component of her professional competence]. Nursing. 2018. Vol. 4. P. 44-46 [In Ukrainian].

5. Ruzhylo N. S., Terenda N. O. Vyvchennia potreby v neformalnii osviti sered molodshykh spetsialistiv z medychnoiu osvitoiu zakladiv okhorony zdorovia Ivano-Frankivskoi oblasti [Study of the need for non-formal education among junior specialists with medical education in Ivano-Frankivsk region health care institutions]. Nursing. 2020. Vol. 2. P. 39-40 [In Ukrainian].

6. Bundesamt für Statistik. Erwerbstätigkeit und Arbeitszeit - Detaillierte DatenDetaillierte Ergebnisse der BESTA. 2015. URL: http://www.bfs.admin.ch/bfs/portal/de/index/themen/03/02/blank/data/02.html.

7. Central Migration Information System, State Secretariat for Migration. Analyses by Swiss Health Observatory. Neuchâtel. 2018. URL: https://www.ncbi.nlm.nih.gov/books/NBK545726/.

8. NAREG. Nationales Gesundheitsberuferegister, Factsheet. Bern: Schweizerische Konferenz der Gesundheitsdirektorinnen und Gesundheitsdirektoren. 2014. URL: https://www.astrm.ch/files/Dokumente/News/Factsheet_ NAREG_20141212_d.pdf.

9. NĀAREG. Nationales Gesundheitsberuferegister. 2015. URL: http://www.gdk-cds.ch/index.php?id=1013.

10. Nursing Care Continuum Framework and Competencies. Geneva, Switzerland: International Council of Nurses. 2008. $43 \mathrm{p}$. 
11. OECD. (2017). Health at a Glance 2017: OECD Indicators. Paris, France: OECD Publishing. Retrieved from: http://dx.doi.org/10.1787/health_glance-2017-en.

12. Pietro de C., Camenzind, P., Sturny I., Crivelli, L., Edwards-Garavoglia, S., Spranger, A., Wittenbecher, F., \& Quentin, W. Switzerland: Health System Review. Health Systems in Transition. 2015. 17 (4). P. 1-288.

13. Poghosyan, L., Aiken, L. H., \& Sloane, D. M. Factor structure of the Maslach burnout inventory: an analysis of data from large-scale cross-sectional surveys of nurses from eight countries. International Journal of Nursing Studies. 2009. 46(7). P. 894-902.

14. Rafferty, A. M., Busse, R., Zander-Jentsch, B., Semeus, W., \& Bruyneel, L. Strengthening health systems through nursing: Evidence from 14 European countries. Copenhagen, Denmark: WHO. European Observatory on Health Systems and Policies. 2019.

15. SBK-ASI. (2011). Professionelle Pflege Schweiz - Perspektive 2020. Bern: Schweizer Berufsverband der Pflegefachfrauen und Pflegefachmanner. Retrieved from: http://www.sbk.ch/fileadmin/sbk/shop_downloads/de/Perspektive2020-dt.pdf.

16. Schwendimann, R., \& et al. Neuchâtel: Schweizerisches Gesundheitsobservatorium. Das Pflegefachpersonal in Schweizer Spitälern im europäischen Vergleich. Obsan Bulletin. 2014. Vol. 3. 